\title{
レジンコンクリートの特性と 構造設計指針（案）について
}

\author{
国枝 稔 ${ }^{* 1} \cdot$ 服部篤史 ${ }^{* 2} \cdot$ 宇治公隆 ${ }^{* 3} \cdot$ 日比野誠*4
}

\begin{abstract}
概 要 レジンコンクリート（REC）の構造設計については, 昭和 60 年に(社)日本材料学会 コンクリート工事用樹脂 委員会から，「ポリエステルレジンコンクリート構造設計計算指針 (案)」が提案された。その後, レジンコンクリートの 結合材屯不飽和ポリエステル樹脂（以下, UP という）からエポキシ樹脂やアクリル樹脂系に拡大し, さらに, 建設分野 の構造設計が, 従来の仕様規定型から性能照查型に移行しつつある。このような状況を背景として, REC の材料特性を 適切に評価し, 合理的, 経済的に所要の性能を達成するための新たな指針「レジンコンクリート構造設計指針 (案)」が 作成された。ここでは，RECの特徴的な材料特性について概説するとともに，改定された指針（案）について紹介する。 キーワード：レジンコンクリート, 設計指針, 性能照査型設計, 而久性
\end{abstract}

1. はじめに

レジンコンクリート（以下， REC という）は，セメ ントコンクリート（以下，コンクリートという）の結合 材であるセメント水和物のすべてを高分子材料で代替し たあのであり, 結合材としての液状レジンに加え, 充填 材，骨材ならびに必要に応じて添加材を加えて製造され た複合材料である。圧縮, 引張, 曲げ強度が高く, 耐食 性, 水密性, 而摩耗性, 電気絶縁性などの優れた性能を 有しており, 現在では, 主として地中の構造体としての 利用が広がっている。

REC の構造設計については, 昭和 60 年に(社)日本材料 学会 コンクリート工事用樹脂委員会から,「ポリエステ ルレジンコンクリート構造設計計算指針 (案) 」1) が提案 された。これは当時の限界状態設計法による REC 構造 物に対する世界初の構造設計に対する考え方を示したも のとして注目された。その後, REC の結合材も不飽和 ポリエステル樹脂（以下，UPという）加らエ゚キシ樹 脂やアクリル樹脂系に拡大し，また，建築学会において 屯,「コンクリート・ポリマー複合体の施工指針（案）・ 同解説」 $\rfloor^{2)}$ が提案されるなど, 材料や適用範囲も多様化 している現状にある。さらに，建設分野の構造設計が， 従来の仕様規定型から性能照査型に移行しつつある。こ のような背景のもと, (社)日本材料学会 コンクリート工 事用樹脂部門委員会（委員長：宮川豊章 京都大学教授） では, 平成 15 年に「ポリエステルレジンコンクリート 構造設計計算指針（案）」(以下，旧指針（案)）の改訂 作業を行うWG（表-1）を設置し，2 年間をかけて, REC の材料特性を適切に評価し, 合理的, 経済的に所

\footnotetext{
*1 くにえだ・みのる/名古屋大学大学院 准教授 (正会員)

*2 はっとり・あっし/京都大学大学院 准教授 (正会員)

*3 うじ・きみたか／首都大学東京大学院 教授（正会員）

*4 ひびの・まこと/九州工業大学 准教授 (正会員)
}

\section{表-1コンクリート工事用樹脂部門委員会 REC 関連事項}

\section{検討 WG 委員}

小柳洽 (主查, 岐阜大学), 井上正一 (鳥取大学), 今井恒雄 (昭和高 分子), 宇治公隆 (首都大学東京), 大島光晴 (サンレック), 大濱嘉 彦 (日本大学), 城戸正久 (日之出水道機器), 久保善司 (金沢大学), 国枝稔 (名古屋大学), 出村克宣 (日本大学), 服部篤史 (京都大学), 林富士男 (サンレック), 日比野誠 (九州工業大学), 松下博 (アソウ レジコン), 宮川豊章 (京都大学), 山口茂 (NTT)

要の性能を達成するための新たな指針「レジンコンクリー 卜構造設計指針 (案) 」3) (以下, 指針 (案)) を作成した。

ここでは，文献 3)〜 7) を再構成し，REC の特徵的な 材料特性や適用事例について概説するとともに, 改定さ れた指針（案）について紹介する。

\section{2. 建設材料としての REC の特徴}

ここでは, REC の建設材料としての特徵を紹介する にあたり, 特に力学的特性と耐久性を中心に記述する。 また，液状レジンとして最も多用されているUPを用い たレジンコンクリート（UP-REC）を中心に述べること とする。なお, 紹介する物性値等については, 使用する 骨材等の影響を受けることに留意されたい。

\section{1 常温における強度および変形特性}

REC の圧縮, 曲げ強度の試験結果の例を, 普通コン クリート抢よび高強度コンクリートの例とともに表-2 に示す ${ }^{8)}$ 。 REC の圧縮強度は, $140 \mathrm{MPa}$ 程度以上であ り, また REC の圧縮強度に対する曲げ強度の比も, コ ンクリートのそれに比べて大きいのが特徴である。寸法

\section{表-2＼cjkstart各種コンクリートの強度試験結果の例 ${ }^{8)}$}

\begin{tabular}{c|c|c|c}
\hline コンクリートの種類 & $\begin{array}{c}\text { 圧縮強度 } \\
(\mathrm{MPa})\end{array}$ & $\begin{array}{c}\text { 曲げ強度 } \\
(\mathrm{MPa})\end{array}$ & $\begin{array}{c}\text { 曲げ荷重下の消散エ } \\
\text { ネルギー (N・mm) }\end{array}$ \\
\hline 普通コンクリート & 44.6 & 4.37 & 29.4 \\
\hline 高強度コンクリート & 110 & 6.10 & 48.0 \\
\hline $\mathrm{UP}-\mathrm{REC}$ & 145 & 18.6 & 29.4 \\
\hline
\end{tabular}




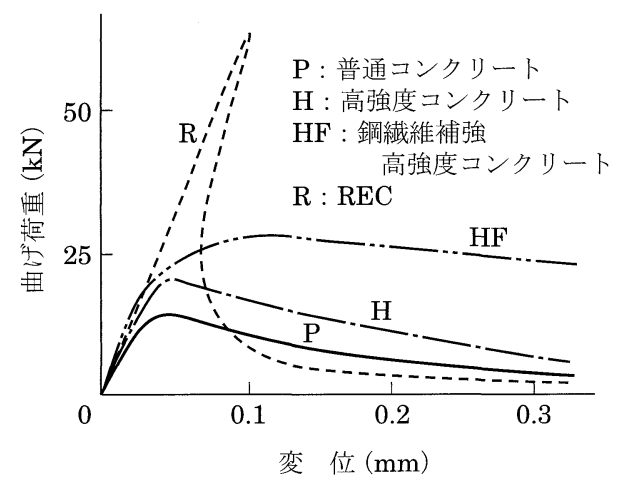

図-1 曲げ荷重-変位（たわみ）曲線

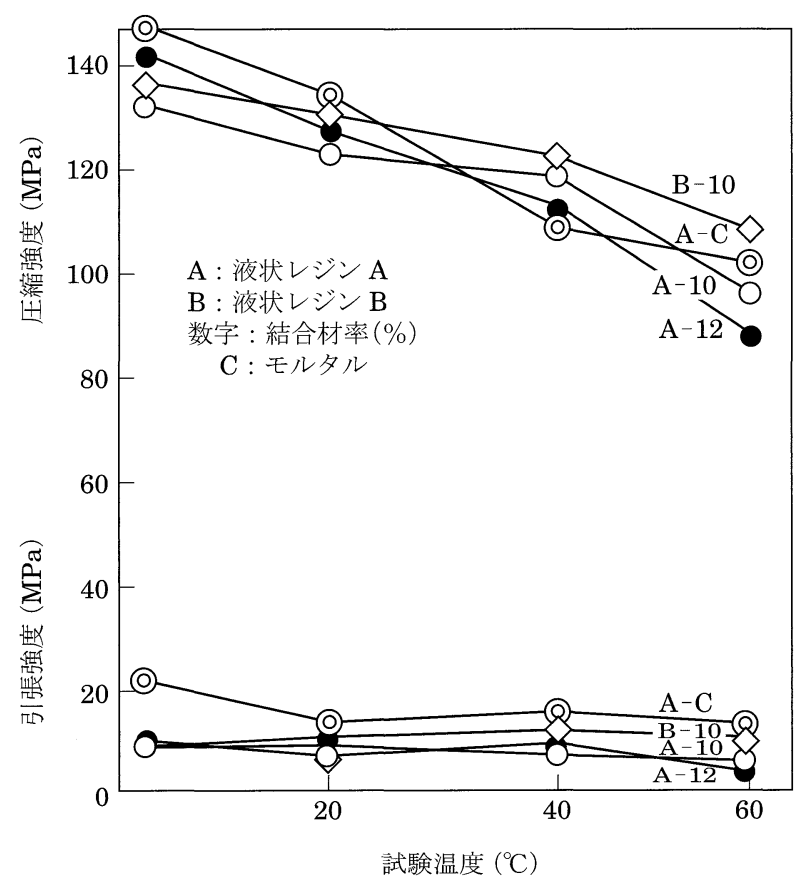

図-2＼cjkstart圧縮および引張強度の温度依存性 ${ }^{9)}$

$100 \times 100 \times 400 \mathrm{~mm}$ の供試体を用いた三等分点曲げ載荷 試験により得られた曲げ荷重一変位（たわみ）曲線を, 図-1に示す。REC では, 耐力が大きいため, 最大荷重 時に供試体に蓄えられるひずみエネルギーが大きく, こ れが一挙に解放されるため, 曲線状にスナップバック （荷重と変位が共に減少する現象）が認められる。

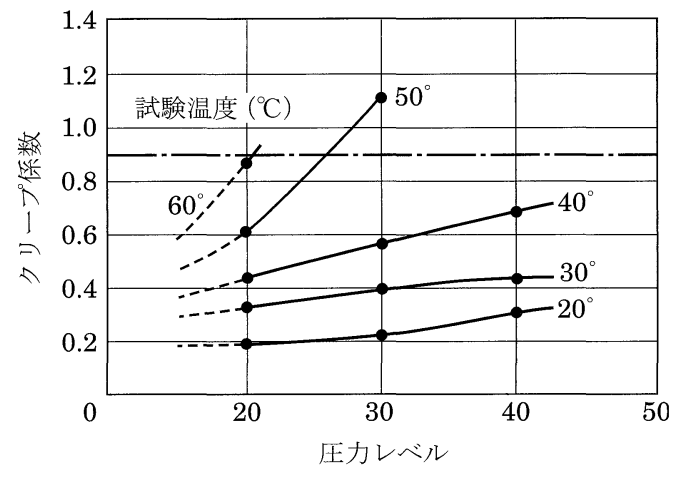

図-3ＵP-REC のクリープ係数（材齢 30 日 $)^{10)}$

\section{2 力学的特性の温度依存性}

$\mathrm{REC}$ の強度や弾性係数は, 温度に依存し, また，使 用する液状レジンの種類によって，その温度依存性は大 きく異なる。

図-2に，UP-REC の圧縮および引張強度の温度依存 性を示す ${ }^{9)}$ 。図中の $\mathrm{A}$ および $\mathrm{B}$ は，液状レジンの種類 を，数字は，結合材量（\%) を，Cは，モルタルを示す。 なお，引張強度は，寸法 $\phi 100 \times 200 \mathrm{~mm}$ の円柱供試体 を用いて割裂引張試験により求めた。温度上昇に伴って 強度が低下する傾向にあり，ここには示していないが， 弾性係数む同様に温度の上昇に伴って低下する傾向にあ ることが知られている。また，図-3に示すように，ク リープにも温度依存性が認められる ${ }^{10)}$ 。

\section{3 耐 久 性}

REC は, 水密性が高く, 凍結融解作用をはじめとす る気象作用や，薬品などに対する抵抗性が高いことが知 られている。ただし, UP は加水分解されるため, 水中 における曲げ強度は, 図-4に示すように, 高温になる ほど低下する傾向にある ${ }^{11}$ 。

耐薬品性については, 強酸性の草津温泉 ( $\mathrm{pH}: 1.8 \sim$

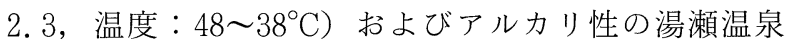

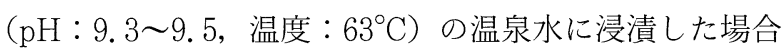
の, 約 15 年にわたる浸漬時間と強度の関係を調べた結 果として，浸漬時間とともに若干強度が低下することが 報告されている ${ }^{11}$ 。

Properties and Recommendation for Structural Design of Polymer Concrete

By M. Kunieda, A. Hattori, K. Uji and M. Hibino

Concrete Journal, Vol.45, No.11, pp.7 12, Nov. 2007

Synopsis In 1985, the Research Committee on Polymers in Concrete in the Society of Material Science proposed "Recommendation for structural design of polyester resin concrete (draft)". Then, many types of polymers (e.g. unsaturated polyester resin, epoxy resin and acrylic resin) have been used as matrix of polymer concrete. In addition, most structural design concept in civil and architectural fields has been changed to performance-based design. In order to apply the polymer concrete to various kinds of applications appropriately, the recommendation was revised in 2006. This paper introduces the fundamental material properties of polymer concrete and the typical examples of applications briefly, and also presents the contents of "Recommendation for structural design of polymer concrete (draft)".

Keywords : Polymer concrete, recommendation, performance-based design, durability 


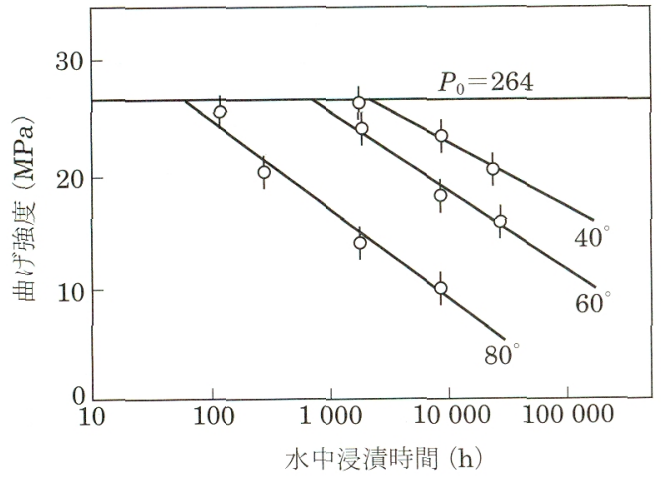

\section{図-4 水中劣化促進試験における曲げ強度と} 水中浸漬時間の関係

\section{4 の 他}

その他の REC の特徵として，(1)接着が容易であり， かつ接着部の强度を母材と同じ程度にすることができる， (2)耐摩耗性が高い，(3)表面が滑らかで光沢があり，美観 に優れ, 洗浄しやすい。また, 顔料による着色が可能, (4)電気絶縁性が大きい，なよ゙がある。

一方で，(1)硬化時の収縮が大きく，鉄筋などによる補 強の効果にコンクリートの場合と晎なる面がある, (2)硬 化時の発熱が大きく, 部材厚の上限を考慮する必要があ る，といった性質は，デメリットとなる場合が多い。さ らに，(3)コンクリートと比べかなり高俩である。

3. 適用事例

\section{1 現場施工}

表-3に示すように, 現場施工には, 路面補修, ダム のエプロンや水路の補修などの工事, 耐食ライニングに よる床工事などが従来から広く行われている ${ }^{12}$ 。路面補 修では，早期交通開放の目的のために， RECの早強性， 接着性抢よび而摩耗性が利用され，水路補修では，これ らのほかに，水密性が利用されている。化学工場の床な よ゙の耐食ライニングには，現場で REC を打設する方法 と，プレハブ用 REC 板を現場で接着する方法との 2 種 がある。

表-3 REC の特性と用途例 ${ }^{12)}$

\begin{tabular}{|c|c|c|c|c|c|c|c|c|c|}
\hline $\begin{array}{l}\text { 区 } \\
\text { 分 }\end{array}$ & 用 途 特 性 & $\begin{array}{l}\text { 早 } \\
\text { 強 } \\
\text { 牲 }\end{array}$ & $\begin{array}{l}\text { 高 } \\
\text { 胎 } \\
\text { 度 }\end{array}$ & $\begin{array}{l}\text { 接 } \\
\text { 性 }\end{array}$ & $\begin{array}{l}\text { 永 } \\
\text { 密 } \\
\text { 性 }\end{array}$ & $\begin{array}{l}\text { 耐 } \\
\text { 酸 } \\
\text { 性 }\end{array}$ & $\begin{array}{l}\text { 恧 } \\
\text { 摩 } \\
\text { 耗 }\end{array}$ & 高 & 観 \\
\hline \multirow{4}{*}{$\begin{array}{l}\text { 現 } \\
\text { 㻢 } \\
\text { 工 }\end{array}$} & 路面補修 & 0 & 0 & 0 & & & 0 & & \\
\hline & 而摩耗ライニング & & 0 & 0 & & & O & & \\
\hline & 耐食ライニング & & 0 & 0 & 0 & 0 & & & \\
\hline & トンネルライニング & 0 & 0 & 0 & 0 & & & & \\
\hline \multirow{4}{*}{$\begin{array}{l}\text { 工 } \\
\text { 場 }\end{array}$} & マンホール & & 0 & 0 & 0 & 0 & & & \\
\hline & パイプ & & 0 & & 0 & 0 & 0 & & \\
\hline & 化粧板 & & 0 & 0 & 0 & 0 & & & 0 \\
\hline & 舗装板 & & 0 & & & & 0 & & 0 \\
\hline 製 & 薬液槽 & & 0 & & 0 & 0 & & & \\
\hline \multirow[t]{3}{*}{ 品 } & トラフ蓋 & & 0 & & & & & & \\
\hline & 工作機械用ベッド & & 0 & 0 & & & & 0 & \\
\hline & 収納庫 & 0 & 0 & 0 & 0 & & & & \\
\hline
\end{tabular}

注目される適用事例としては, 寒冷地の低温下での道 路舗装材として, $-20^{\circ} \mathrm{C}$ で屯硬化可能なアクリル酸エ ステル RECの例や, RECの早強性, 高強度, 接着性 および水密性を利用した小口径トンネルライニングの現 場自動施工なぶが挙げられる ${ }^{137}$ 。また，損傷 RC 床版の 補修工法として，炭素繊維シートとの併用による補強工 法なぎも提案されている19》。

\section{2 工場 製品}

REC は短時間で硬化させることができるので, 工場 生産をする場合には，(1)型枠回転率が向上し，型枠数が 少なくてよい，(2)養生用の設備が少なくてよい，などの 利点老有するため, 設備生産性が高い。

工場製品には，高強度のほかに，耐食性，水密性，而 摩耗性など種々の特性を利用した例が多い。以下に挙げ るマンホール類などのほかに, 板類, 化粧材, 振動減哀 特性を利用した工作機械などの精密機械の台座などに使 用されているが，近年，人造大理石製品の需要が年々増 加して抢り，システムキッチン，洗面台などが製造され ている ${ }^{15)}$ 。以下に主な適用例を述べる。

(1) マンホール類

通信分野におけるブロックマンホールは，1970 年以 前に実用化され，既に，全国で 25 万個程度が製造され ている。また, 電力分野では地下送電線の接続, 分岐, 保守のためのマンホールや，その他に，ガス，水道の弁 室用, 下水道用マンホールなどにも使用されている（写 真-1)。硫酸浸食によって損傷劣化した下水道マンホー ルの復旧に REC 製のマンホールを採用した事例が報告 されている ${ }^{16)}$

(2) パイプ

REC 管は，鉄筋を配した型枠に，練り混ぜた REC

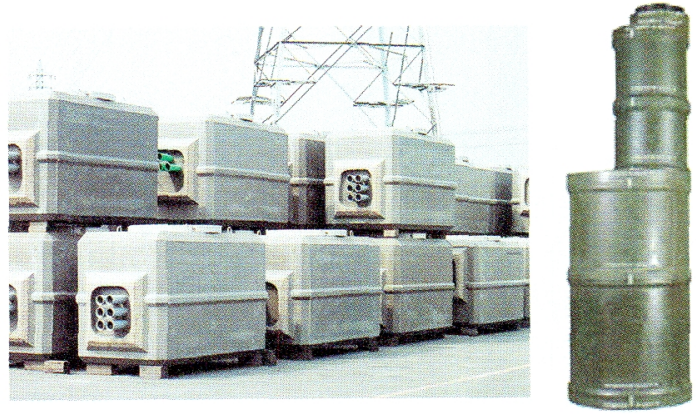

写真-1 通信用および下水道用マンホール

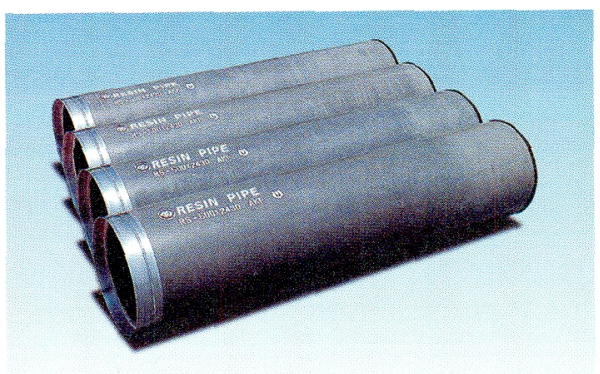

写真-2 REC 製推進管 
を投入し，遠心成形して製造する（写真-2）。我が国に 押いては, 1985 年に, 下水道分野において REC 管が初 めて採用された。この分野において問題となっている硫 酸に対してはもちろんのこと, 温泉水, 酸性土壤, 海水 に対しても REC の代表的な特性が活かされ，広く用い られている。近年，污水管としての利用のほかに，酸性 土壌対策のために，雨水配水管に REC 管が用いられた 事例がある。

(3) REC セグメント

REC を下水道用シールドトンネル用セグメントに適 用する検討が行われている。高強度, 而薬品性などの利 点を生かすことにより，二次覆工が省略でき，建設コス 卜の縮减や工期短縮が図れる点が注目されている ${ }^{17)}$

（4）地下収納庫，薬液槽など

建築用途での埋設構造物としては，住宅用地下収納庫 がある。これは，住宅の地下に埋設される大型の倉庫と して開発されたもので，地下に設置することにより，土 地の有効利用ができ, かつ外部気温変化の影響が少ない という長所がある。その他に，REC の優れた耐食性を 利用したものとして酸性液のタンクや化学薬品のポンプ 台, 排水溝, 薬品処理槽などに使用されている例がある。

\section{4. 指針改定のポイント}

\section{1 REC 構造物, 部材の耐荷性}

旧指針（案）の特徴は，(1)当時最も実験デー夕が豊富 であった UP を用いた REC を対象としていること，(2) REC 構造物の部材断面の決定に関し, REC の力学特性 に立脚した部材の設計計算を対象としていること，(3) REC の強度の利用形態と部材の種別によってタイプ I からタイプIVまで区分して考えること，などである。し かし, 実際の REC の利用形態を勘案すると, 夕イプI （曲げ部材，基本的には無筋）に相当する部材がほとん ぞであり，言い換えれば，タイプIからタイプIVに該当 する部材の利用実績や実験的な裏付けデー夕が少ない。

今回の改定に扔いても，設計の基本的な考え方として， 性能照査型の設計を念頭に, 限界状態（使用限界状態招 よび終局限界状態）に関しての照査を行うこととした。 すなわち，設計では，日常的な供用において想定される 限界状態である使用限界状態，および部材に最大荷重， 最大变位が作用した状態である終局限界状態を設定し， 施工中あるいは設計耐用期間中に扔いて，部材がそれぞ れの限界状態に至らないことを確認することで，構造物， 部材の性能を照査する。なお，疲労限界状態に関しては, 十分な情報が得られていないのが現状である。

次に, REC 部材を，強度の利用形態や部材種別によ り，表-4の 3 タイプに分類した。これは，基本的には 旧指針（案）の手法が踏襲できるとしたあのであるが， 旧指針のタイプIV（その他の部材としてタイプIII とは別 に分類）は，実績が少なく，区分として不明瞭であるた
表-4 REC の分類および特徵（指針（案）による）

\begin{tabular}{|c|c|c|c|c|}
\hline 種 類 & 主な対象部材 & 耐荷特性 & 使用限界状態 & 終局限界状態 \\
\hline タイプ I & $\begin{array}{l}\text { 曲げ部材（基本 } \\
\text { 的に無筋。現在 } \\
\text { のほとんどがこ } \\
\text { れに対応） }\end{array}$ & $\begin{array}{l}\text { 高い曲げ強度を } \\
\text { 利用（ただし， } \\
\text { 脆性破壊を防止 } \\
\text { するため, 用心 } \\
\text { 鉄筋を配置) }\end{array}$ & $\begin{array}{l}\text { 曲げ引張に対 } \\
\text { する応力度の } \\
\text { 制限 }\end{array}$ & $\begin{array}{l}\text { 曲げひび割れ } \\
\text { 発生時 }\end{array}$ \\
\hline タイプ II & $\begin{array}{l}\text { 曲げ部材（鉄筋 } \\
\text { を配置したはり， } \\
\text { スラブ部材など） }\end{array}$ & $\begin{array}{l}\text { REC で压縮力 } \\
\text { を, 補強材で引 } \\
\text { 張力をを負担 }\end{array}$ & $\begin{array}{l}\text { 曲げひび割れ } \\
\text { 発生時 }\end{array}$ & 部材耐力時 \\
\hline タイプIII & $\begin{array}{l}\text { 圧縮部材（柱, } \\
\text { 杭など） } \\
\text { その他 }\end{array}$ & $\begin{array}{l}\text { 圧縮部材では圧 } \\
\text { 縮強度を利用 }\end{array}$ & $\begin{array}{l}\text { 目的ごとに設 } \\
\text { 定 }\end{array}$ & $\begin{array}{l}\text { 目的ごとに設 } \\
\text { 定 }\end{array}$ \\
\hline
\end{tabular}

め，タイプIIIに包含している。

例えば，タイプI の部材では，部材内に生じる応力が 応力度の限界值以下であることを確認することで使用限 界状態の照查を行い，また，部材内に生じる応力がひび 割れ発生応力以下であることを確認することで，終局限 界状態の照査を行うこととなる。

構造設計に必要な，荷重㧍よび環境条件，材料の設計 用值，構造解析の方法，構造物の安全性や使用性の照査 方法などについては，5章に後述する。

\section{2 REC 構造物, 部材の耐久性}

土木学会コンクリート標準示方書［施工編］2002 年 版などでは，コンクリートの耐久性を照査する際に，中 性化, 塩化物イオンの浸入に伴う鋼材腐食, 凍結融解作 用，化学的浸食，アルカリ骨材反応，水密性抒よび而火 性のうち必要な性能について照査を行うこととされてい る。REC の耐久性に関しても, 適切に性能を設定し, それを照查することが望ましい。旧指針では，耐久性に 関する実験デー夕や実例が少なかったことや，REC 構 造物の供用期間内では十分な耐久性が確保できることを 想定していたため，その記述がなかった。

改定された指針では，実際の適用例が多く，しかむ実 験デー夕が比較的多い UP-REC を中心に, 土木学会コ ンクリート標準示方書［施工編］2002 年版などを参考 にしながら，耐久性に関する記述がなされた。

5. レジンコンクリート構造設計指針（案）の概要 ここでは，改定された指針（案）の概要を紹介する。 指針（案）の目次を表-5に示す。な㧍，指針（案）の 全文は，文献3）に記載されているので参照されたい。

\section{1 概 要}

今回改定された指針（案）においても，基本的には UP を中心としたREC を適用範囲として挙げている。 しかし，今後，UPだけでなく，エポキシ樹脂やメタク リル酸メチルを主成分とするアクリル樹脂（MMA 樹 脂）などへの適用も妨げることのないよう留意した。

\section{2 構造設計}

（1）荷重㧍よび環境条件

設計耐用期間中に作用する荷重を選定することは極め 


\section{表-5 レジンコンクリート構造設計指針（案）目次 ${ }^{3)}$}

\begin{tabular}{|l}
\hline 第 1 章 総則 \\
1.1 適用範囲 \\
1.2 用語の定義 \\
1.3 記号 \\
第 2 章 設計の基本 \\
2.1 照查の原則 \\
2.2 限界状態に基づく REC 部材の区分 \\
第 3 章 荷重拉よび環境条件 \\
3.1 一般 \\
3.2 荷重の特性値 \\
3.3 荷重の種類 \\
3.4 環境条件 \\
第 4 章 材料特性と設計用值 \\
4.1 REC 諸性質 \\
4.2 補強材の諸性質 \\
第 5 章 構造解析 \\
第 6 章 REC 構造物の安全性照査 \\
6.1 一般 \\
6.2 曲げモーメントおよびせん断力に対する安全性の検討 \\
第 7 章 REC 構造物の使用性照査 \\
7.1 一般 \\
7.2 応力度の算定 \\
7.3 応力度の制限値 \\
7.4 変位・変形に対する検討 \\
第 8 章 REC 構造物の耐久性照査 \\
8.1 一般 \\
8.2 耐久性の検討 \\
\hline
\end{tabular}

て難しく，また，主に地中構造物として利用される $\mathrm{REC}$ 構造物では, 施工時の荷重が大きくなることが予 想される。荷重の選定にあたっては, 土木学会コンクリー 卜標準示方書, 道路橋示方書, 鉄筋コンクリート構造計 算基準・同解説などの構造設計関連の基準類を参考に, 適切に設定しなければならない。

\section{（2）材料特性之設計用值}

平成 17 年 3 月に公示された, JIS A 1181「レジンコ ンクリートの試験方法」により, 適切に試験を行い, そ の結果をもとに REC の特性值を決めるのがよい。ただ し, 試験に用いる供試体の寸法と実際の部材の寸法が大 きく異なる場合には，適切な供試体寸法を設定するか， 強度の寸法効果を考慮した特性値を用いることとなる。

さらに, REC 構造物に補強材 (連続瀻維補強材, 短 繊維補強材）を用いる場合には, それらの規格值の下限 值を用いるか，適切な試験により特性值を定める必要が ある。

\section{（3）構造解析}

タイプIでの利用（ひび割れのない範囲での利用）が 主である現状を踏まえ, 弾性理論に基づく近似解法もし くは有限要素法による。さらには, 補強材の量が比較的 少なく，かつひび割れを許容しない部材であれば，補強 材の断面 2 次モーメントを無視して断面力あるいは変形 を算定することができる。これらの算定にあたっては， REC の収縮に伴って発生する内部応力や, 各種物性の 温度依存性を適切に考慮する必要がある。

\section{（4）構造物の性能照査}

構造物あるいは部材の性能（安全性㧍よび使用性）照 査は，設定された限界状態において，部材に生ずる断面 力が，設定した環境下での部材の断面耐力以下であるこ とを確認することで行う。

それらの限界状態のうち, 主に用いられるタイプ I の 部材の使用限界状態では, 曲げひび割れ発生時より小さ な応力度である応力度の制限値を用いる。この制限値は, 構造物の重要度や環境条件, 供用期間などを考慮して定 める必要があるが, 地中構造物以外の用途屯対象とした 一般的な制限值を示すことは現時点では困難である。こ 机に対し, 指針 (案) では, 徒来の許容応力度法に従っ た設計実例を基に，REC の設計基準強度を「応力度の 制限係数」（一般に 2.0 4.0) で除した值を, 曲げ引張, 曲げ圧縮の両者に対する応力度の制限値としている。

一方, タイプ II から开に関しては, 実験データが十分 に蓄積されていないため, 土木学会コンクリート標準示 方書などを参考に，適切に照查する必要がある。

（5）その他（構造細目など）

$\mathrm{REC}$ を用いる場合, 高強度特性を活かすことで, 部 材厚を薄くすることが可能となるが，タイプI の用心鉄 筋も含め, 鉄筋を有効に機能させるためには, 粗骨材の 最大寸法や鉄筋同士のあきなどを適切に考慮することが 重要である。

\section{3 耐 久 性}

耐久性に関しては，コンクリートにおける中性化，塩 害, 硫酸浸食などの劣化が顕在化する構造物に対して, 補修時に部材の一部あるいは部材全体を REC で置換す る事例むある。しかし，実際にはREC の高い耐久性を 適切に照査し, 設計に反映させるための具体的な方法に ついて明確にはされていなかった。これに対し，指針 （案）では，耐久性に関する既往の知見に基づき，REC の耐久性の照查方法に関する考え方についての記述を試 みた点にも特徵がある。

具体的な耐久性に関する検討では，ひび割れを許容し ない構造物（部材）を対象とすることを基本とする。こ れは，(1REC が中性であり，少なくともひび割れ部で の鉄筋の防錆作用はないむのと考元られている点, (2) REC の高い引張強度を利用し， かつ REC が大きな収 縮ひずみを有するため, 補強材（例えば鋼材）は配力筋 や終局時の崩壊を防ぐ之いう目的でのみ用いられている 点, による。特に, REC 中の鋼材の腐食によるひび割 れ発生メカニズムやそれらが部材の性能に与える影響に ついては明らかにはされておらず，ひび割れ部を含めた 耐久性の照查手法については, 現段階ではデー夕も十分 に蓄積されていない。ひび割れ部を対象とした耐久性の 照査方法については, デー夕の蓄積む含め, 今後の課題 である ${ }^{18) 。}$

コンクリートの耐久性を照査する際には，考慮すべき 
種々の照査項目が示されているが，REC を対象とした 指針（案）においては，塩化物イオンの浸入に伴う鋼材 腐食, 凍結融解作用, 化学的浸食, 耐水安定性および而 候性のうち, REC 構造物のおかれる環境を考慮して, 必要なものについてのみ照査を行うこととした。REC を対象とした場合, 結合材として用いる液状レジンが中 性であるため, 中性化やアルカリ骨材反応については対 象外亡し, 水密性については, RECの物質透過に対す る抵抗性が極めて高いこと, 使用時にひび割れを許容し ない範囲を対象とした照査であること, 適切な試験方法 が十分に確立されていないこと, などを勘案し, 照査項 目から除外している。さらには, 耐火性についても, そ の利用形態が地中構造物であり, かつ適用の温度範囲が $50^{\circ} \mathrm{C}$ 程度以下であることから, 照査の対象外とした。 先にも述べたが, これらすべての項目について照查を行 う必要はなく, 構造物のおかれた環境などを勘案し, 特 に耐久性に著しく影響を及ぼすと考えられる項目につい てのみ照査を行うこととし, 耐久性に関する照査方法に ついては，例えば，土木学会コンクリート標準示方書な どあ参考にするとよい。

\section{6. おわりに}

ここでは，REC の材料特性を踏まえた REC 構造設 計指針（案）を紹介した。RECの長所，短所を理解し たうえで，本指針をもとに， REC の優位性を利用した 適用がより進むことを期待したい。

謝 辞 本原稿を執筆するにあたり，日本材料学会 REC 関連事項検討 WG の委員の皆様に多大なるご協力 をいただいた。ここに記して謝意を表します。

\section{参 考 文 献}

1）日本材料学会コンクリート工事用樹脂委員会：ポリエステルレジ ンコンクリート構造設計計算指針（案），Vol.34，No.386， pp.1110 1114, 1985

2）日本建築学会：コンクリート・ポリマー複合体の施工指針（案）・ 同解説， 2001

3）コンクリート工事用樹脂部門委員会：レジンコンクリート構造設 計指針（案）について, 材料, Vol.55, No.1, pp.122 130, 2006

4）大濱嘉彦・山口 茂：レジンコンクリートの特性と構造利用 1 . 建設材料としてのレジンコンクリート，材料，Vol.54, No.9, pp.971 978, 2005

5）日比野誠・今井恒雄・城戸正久・松下 博：レジンコンクリート の特性と構造利用 2.レジンコンクリートの製造に関する技術, 材料, Vol.54, No.10, pp.1087〜1093, 2005

6）林富士男・大島光晴・佐藤隆治・小柳 洽：レジンコンクリート の特性と構造利用 3, レジンコンクリートの性能と試験, 材料, Vol.54, No.11, pp.1197 1203, 2005

7）国枝 稔・服部篤史・宇治公隆：レジンコンクリートの特性と構 造利用 4.レジンコンクリート構造物の性能設計と将来展望, 材 料, Vol.54, No.12, pp.1314 1320, 2005

8）小柳 洽・六郷恵哲・内田裕市：コンクリートの破壊現象の安定 性とその計測, コンクリート工学, Vol.20, No.6, pp.83〜89, 1982

9) K. Okada, W. Koyanagi and T. Yonezawa : Thermo-dependent properties of polymer resin concrete, The Construction Press, pp.210-215, 1976

10）山崎竹博・出光 隆・渡辺 明・宮川邦彦: 不飽和ポリエステル レジンコンクリートのクリープ特性に関する研究, 材料, Vol.40, No.456, pp.1178〜1184, 1991

11）小柳 洽：Polymers in Concrete一新しい動向一 4. レジンコ ンクリートポリマー含浸コンクリートの利用, 材料, Vo.41, No.470, pp.1709 1716, 1992

12）小柳 洽・林富士男：レジンコンクリートの利用の現状，コンク リート工学, Vol.23, No.10, pp.26〜33, 1985

13）高塚外志夫・岡田武司・近藤章司・中西信輔：自動トンネル築造 工法に打けるライニング技術の研究開発, 土木学会論文集, No.355/VI-2, pp.91〜99, 1985

14）堤下隆司・栗田章光・徳岡文明：MMA 樹脂コンクリート上 CFS との併用による損傷 RC 床版の補強工法に関する研究, 上 木学会論文集, No.774/V-65, pp.1〜 15, 1985

15) Y. Ohama: Recent progress in research and development activities of concrete-polymer composites in Japan, Proc. of 11th International Congress on Polymers in Concrete, Berlin, Germany, pp.605-612, 2004

16）日経コンストラクション（2004 年 11 月 12 日号), pp.62〜 63, 日経 BP 社, 2004

17）近 信明・斉藤正幸・石川隆司・大槻 敬：レジンコンクリート ライニングシステムの開発, 土木学会第 55 回年次学術講演概要 集, 第VI部門, pp.45〜 46, 2000

\section{JCI 規準集（1977－2002）}

本規準集は, 研究専門委員会が冊子，委員会報告書などに提案した規準類を集大成したあのであり，アーカイブスとして貴重 な 1 冊となろう。

なお，掲載した規準類には，作成委員会名，委員会報告の概要および関連情報など付した。

*目次を当協会ホームページ（URL：http://www.jci-net.or.jp）にてご覽いただけます。

A 4 判・592 ページ (2004 年刊行)／定価 10500 円（税込), 会員特価 8400 円（税込)／送料 500 円

- 申込先：(社)日本コンクリート工学協会「書籍販売」係

テ102-0083 東京都千代田区㭳町 1-7 相互半蔵門ビル 12 階／電話（03）3263-1573 